\title{
A Savior Sent by an "Old Foe"; Feridun Demokan, Notes on the Great Famine in Greece
}

\author{
Ulvi KESER ${ }^{1}$
}

\begin{abstract}
The Second World War has had a great and bitter impact upon the countries which participated in it. Unfortunately, one of those countries suffered tragic consequences of the war since it was invaded twice firstly by Italy, and then by Germany. Out of the military invasion, Greece also suffered from the starvation which lasted approximately 5 years in the country. This long and terrific period is

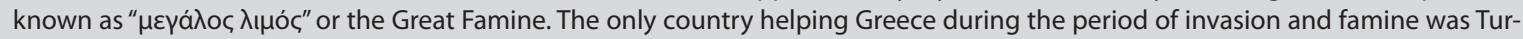
key, and a distinguished Turkish man named Feridun Demokan brought the Greek tragedy into the public attention and informed the entire world about this disaster. This article will focus on the period of Greek famine and the activities of Feridun Demokan who worked as the representative of the Turkish Red Crescent Society.
\end{abstract}

Key Words: Greece, Turkey, red crescent, red cross, grand famine, starvation, WWII

\section{INTRODUCTION}

World War II broke out just after Germany attacked against Poland on 1, September 1939. Similarly, Italy dreaming to expand its territories in the Eastern Mediterranean and the Balkans invaded Albania in April 1939, just following the plans of Germany and made a bridgehead in the Balkans (Soysal, 1983; 591). Turkey trying to take the objectivity and neutrality as soon as the war broke out came face to face with a good many pressures to participate in the war and to follow impartiality policy in favor of the warring parties (Armaoğlu ;407). Due to Turkey's strategical importance, Turkey's position is nothing but the history of the efforts, pressures, and the attempts made by both the Allied and the Axis Forces to join Turkey in the war in favor of them. Out of all these efforts made by warring parties, Turkish policy was to be out of the war and to keep the country away from the danger of the war. Moreover, Turkish and Greek policies regarding the developments in Europe were thoroughly similar. Greece, having had the unilateral guarantee from France and England, seemed to be relaxed, and Turkey then announcing a joint declaration in May and June 1939 with above-mentioned countries installed the base of the tripartite treaty of Turkey, France and England to be signed in October 1939 (Deringil, 1994; 123). Against this background, the main purpose of this article is to focus on an im- portant but unknown historical person named Feridun Demokan who was a dominant figure during WWII, and especially during all those assistance activities.

\section{2- ITALIAN AND GERMAN INVASION IN GREECE}

Italian Ambassador Grazzi (Moos, 1952; 107) in Athens gave an ultimatum to Greece on 28, October 1940 asserting that Greek government gave all its continental shelf, the seas, ports and the air bases to England, and he demanded that Corfu, Preveze, Piraeus, and Crete be handed over to Italy (Hatipoğlu, 1997; 223). Italian dictator Mussolini had, in fact, launched the occupation of Greece with no precise war aims at all, but regarding Greece a piece of cake (Gürel, 1993; 48) imagined to serve Greece "like a fried chicken" (Vatan, 1st January 1941) to Germany but Greek Prime Minister Metaxas refused the Italian offer with no hesitation. On the other hand, Greek soldiers did not only fight against the Italian forces but also fought against the terrific weather conditions in winter. Despite the fact that Greece had almost no powerful military resistance against Italy, Greek people had played a gallant part against the invading forces and subsequent to a series of energetic counter attacks, Italian forces were forced to retreat back. 
On the other hand, Greek people almost little knew that from the moment they had fought the Italian forces off their country the German attack was a foregone conclusion as well (Ulus, $23^{\text {rd }}$ April 1941);

"Greek people forced the Italian forces being doubled in military power to leave their country, and then chased after them. They defeated the small giant force in front of our very eyes. Thus that defeated giant force called help from the bigger giant."

As soon as the Greek Army fought the Italians off their country with astonishing success, throughout all Europe, the news spread of this setback against the Axis prestige again, and British authorities, on the other hand, believed that it would be very possible to resist against the Axis powers in the Balkans if Turkey were to join in this resistance as well. Winston Churchill attaching importance to helping Greece and necessitating this situation so as to keep English prestige in Turkey stated that "Turkey is, as usual, the key point of their Balkan strategy". Soon after Greece stopped Italian attacks, English powers were unable to supply this country with the necessary military assistance to defend Greece (Bilge, 1996; 19). Therefore it was a well-known fact that German invasion of Greece was by all odds not very far away, and Germany avoiding Yugoslavian rebellion there launched the first attack on Greece on 6 April. Despite the fact that Hitler actually did not want to invade Greece at first while Greek Army was also uneager to make war against such huge military forces, seeing what happened to Italian troops trying to invade Greek territory, Hitler changed his opinion and the mission carried out there. Greek military force was unfortunately unable to resist against the Nazi forces and Greek Army at last surrendered on 24, April 1941 , and the first German troops started entering the capital city of Greece 3 days later. What is more interesting at this point is that especially Turkish journals have shown a tremendous reaction against British indifference, reluctance and unawareness to help the Greek people in need as well as Turkish support for Greek people (Ulus, $23^{\text {rd }}$ May 1941).

\section{3- HUMAN AID ACTIVITIES FOR GREECE}

Turkey was the first and the sole country giving hand and helping Greece that was firstly invaded by Italy and then by Nazi Germany. The very sincere and friendly approach of Turkish people for the invaded Greece reflected itself similarly in current Turkish journals. The expressions such as "our friend and ally", "to a neighboring country attacked fier- cely against its freedom, and its right of living in a humanistic way",(Milliyet, $10^{\text {th }}$ August 1974) "regarding the suffering of a brother country that dies" (Vatan, $1^{\text {st }}$ October 1941), "our devastated neighbor; Greece"(ikdam, 28 $8^{\text {th }}$ May 1942), "our friend and ally" (ikdam, 31 $1^{\text {st }}$ May 1942) "two brother countries, two brother houses"(Vakit, 29 ${ }^{\text {th }}$ March 1942) were nothing but the reflection of Turkish nation that forgot the past, and that looked at future safely.

Because of the wartime disruptions in the country especially in the first years of the war, the harvest of most crops was around 15 and 30 per cent lower than it had been before the war. Grain and other foodstuffs had to be collected from the farmers but due to the complexity of the gathering foodstuffs from the fields after Venizelos' land reform, it was almost impossible to do so, and all these negative factors such as the farming system, the structure of the market, popular attitudes, social factors, German forces plundering the country, the panic, and the famine all burdened on Greek people's shoulders, and at long

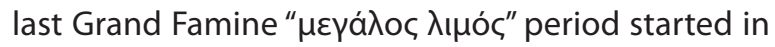
the country. Since German soldiers who were undernourished, exhausted and half-starved brought no food with themselves to Greece, and they started gathering and confiscating everything such as flour, cheese, bread, and meat in the country, and since German war industry supplied almost all the urgent needs from the factories, mines and the fields of the defeated countries such as Greece, the inconvenience of raw material in addition to the unemployment appeared to be seen while the army and the government stocks started decreasing. Over all, in the first days of the occupation, Nazi forces preferred to stay not in the camps but in the private houses and in the hotels in Greece so as to protect themselves from the bombings and the attacks. Due to the plundering, the German authorities warned Berlin, and advised that the army should bring food into the country rather than taking it out (Mazower, 1993; 24). The atrocities and starvation committed by German occupation forces were exactly barbaric, and because all the resources of the country were taken over by Nazi forces, poverty, famine and turmoil were all mingled in Greece. Especially in the prosperous and industrious big cities like Athens and Piraeus, the Greek people were depressed, war-shaken and starving to death. In those above-mentioned cities, due to the starvation and the fierce conditions of the war-torn life, there were almost no cats and dogs in the streets. So as to solve the starvation and to help the people, the first thing to do was actually to supply sufficient food-stuffs immediately. In addition to Greek 
government, some organizations as well took steps and tried to find out radical precautions. Therefore a Greek delegation of former Greek Foreign Minister B. Mavromichalis, retired Air General G. Reppas, the Director of Aerial Air Company B. Nikolopulos, B. Pollis who had organized Turkish-Greek exchange activities, former Minister of Treasure B. Kremesis, banker Kuramyanos, the Director of National Economy Ministry Triyandafilis, journalist B. Zarifis made a visit to Turkey, not to the USA and the western countries (Vatan, $1^{\text {st }}$ October 1941).

On the other hand, Greek people suffering from the starvation regarded that the famine and misery reached the final stage and their whole race was threatened with complete extinction, and it was thoroughly believed that behind the starvation was a deliberate German policy of genocide. Greek people trying to survive, therefore, strictly accused Germans of destroying food rather than letting Greeks have it, and almost all the Greek people were convinced that hunger was the Germans' secret weapon and that was systematically used against these poor people for the purpose of their deliberate extermination. Actually German forces in Greece had no deliberate intention of Greek extermination causing their starvation; but all they did when they heard of the Greek screams from Greece was to turn a deaf ear to the screams coming from Greece.

\section{4- A BALLAD NAMED KURTULUŞ}

Turkey trying to find out the ways and the precautions for Greece finally prepared a strategical plan, and then a cargo ship named Kurtuluş that would be just a ballad during WWII came forward to transport humanistic aid to Greece. Kurtuluş which was manufactured in the United Kingdom in 1883 by Caird Purdie\&Company and Barrow Shipyard Company belonged to Hüsnü Bey on behalf of Tavilzade Family dealing with sea transportation (KGMA. K. No. 2603, D. No. 1941-1943/9-4). Kurtuluş was actually a general cargo steamship having 2 cylinders with 900 horse-powers for the transportation. The first name of the ship when it was launched was Euripides (BCA.030.18.1.2.94.17.17.). In 1915, the ship had a military mission and it was registered to Russian Navy for the military transportation stuffs. In 1918, the ship was again out of the military missions with the name of Michail Archangel, and it started making tours to Istanbul as a Serbian-flagged ship. Six years later, the ship, once more, started sailing in Turkish continental shelves with a new and Turkish name as Teşvikiye for two years. The ship once more was handed over in 1926, and it was sold in 1930 and in 1933 as well with the name of Bülent. Finally, it was bought by Mustafa Tavilzade on behalf of Tavilzade Family in 1934, with the name of Kurtuluş.

\section{5- FERIDUN DEMOKAN'S FIRST APPEARANCE FOR GREECE}

Greece was under invasion and occupation, and the Greek people were all suffering from starvation as well as the Nazi boots. Turkey as a neighboring and friend country started making some organizations, and planning something to help both Greece and the Greek people. The ship named Kurtuluş was ready to sail out and to transport food-stuffs towards Greece, and Feridun Demokan was going to be appreciated by the Greek people soon. Feridun Demokan himself graduated from Galatasaray High School in Istanbul, and Istanbul University Department of Economics. Feridun Demokan's family left lonia during the Balkan Wars (1912-1913), and moved to Anatolia, now he was back in Greece to provide aid for the country his family was forced to leave. He had the chance of practicing Greek language during his years at Galatasaray High School by the help of a classmate called Yuvakim. He later became fluent in Greece when he was studying at Istanbul University and at Ecole Des Sciences Politiques, and finally he visited Greece 18 times as a journalist and ideal representative for humanistic aid program of Turkish Red Crescent Society by the cargo ship named Kurtuluş. When he was called for humanistic assistance program for Red Crescent Society, he was doing his military service in Izmir, and he was ready for all the duties for the country. He also visited a lot of countries, and spent 4 years in France. He was the editor and the publisher of some newspapers such as Turkey Today and Contemporary Turkey. Feridun Demokan worked also at Bank of Real Estate of Turkey for 4 years in Istanbul and Ankara. He was a correspondent for the Turkish newspapers in Paris starting from 1934 up to 1938. Therefore, during the German occupation in Greece, he was appointed as Extra Delegate of the Turkish Red Crescent Society and the International Red Cross. As stated below, he made eleven trips between Turkey and Greece when he was in charge to deliver the foodstuff boarded in Turkey for the starving people of Greece as the chairman of the Red Crescent mission. His fluent Greek made everything easier, and he was firstly invited to Ankara from Izmir by Turkish Red Crescent Society Directorate, and Demokan burdened the responsibility of being Extreme Delegate of Red Crescent Soci- 
ety for Greece mission. Feridun Demokan who had almost no relation with Red Crescent Society, and who had little information on the humanistic aid programs was, actually, a reserve officer in the Turkish Army, and he had been recently deployed to Cairo, Egypt with a military mission as a liaison officer, but he accepted the new mission with no hesitation. When Feridun Demokan came to Ankara, his two passports from Turkish Foreign Ministry and International Red Cross Organization had already been ready, and he himself was ready as well for the mission towards Greece together with his colleague Saim Umar being the delegates of Red Crescent Society as expressed by Demokan himself (KGMA Feridun Demokan Private (Diary) Archive);

"The year was 1941, and Greece was under the invasion of Italian and German troops. Turkey was the ally of Greece through Balkan Entente, but Turkey kept its neutrality regarding the interest of the allied countries... Greece used to supply its food needs with the help of foreign countries, and when it was under the invasion and when all the roads were closed, the country started suffering from the starvation. The Nazi troops in Greece had also confiscated all the available food and even the gardens monitoring the fields with the armed soldiers. Thus Greek people who were devoid of the fresh vegetables and the fruits were sentenced to the starvation in time. The vegetables and the fruits grasped from the Greek people by Nazi forces were all taken to African Corps by German military cargo planes taking off Hassani (now Ellinikon) and Tatoy airports. The schools were closed, and the people in the hospitals, the orphans in the orphanages were out of the milk and the food to eat. Those who lost their lives were burdened into the trucks and were dumped on the mass graves. There were even no cats and no dogs in the cities...."

Having completed all the preparations for the humanistic aid to Greece, the ship named Kurtuluş sailed out from Izmir for her maiden voyage on 14, October 1941 (Vatan, 13 $3^{\text {th }}$ October 1941) taking all the food-stuffs from Turkey, and followed the destination and the route ordered by British and German authorities as well on the pursuit of German aircraft flying over it closely and on a "drunk-way" route having zigzags to Piraeus. Kurtuluş on which a big size of Red Crescent emblem was painted (Ulus, $22^{\text {nd }}$ January 1942) was burdened the cargo of 50 tons of rice, bean, medical aid kits, cloth valued 14.400 Turkish liras (Ulus, 22 ${ }^{\text {nd }}$ January 1942) containing 403 kilos of chick-pea, 404 kilos of bean, 253 kilos of onions, 500 boxes of eggs, 300 kilos of milk and cream, 10 tons of rice, 1.650 kilos of lentil, 5 tons of sugar, 5 tons of varied food-stuffs, salted lonito, and 45 sacks of foodstuffs (KGMA. K. No. 2603, D. No. 1941-1943/9-4.), and turned back to Izmir on 24, October 1941 Friday (Vatan, $13^{\text {th }}$ October 1941). The ship in its very initial voyage was accompanied by German warships and passed through the mine fields at the sea, and was welcomed by German soldiers in Piraeus. The ship anchored in a relatively safe and undamaged area of the port passing "through the ship corpses and the mine fields." (KGMA Feridun Demokan Private (Diary) Archive) Then, not only the ship itself but also the crew and all their belongings and the equipment were controlled, detected and finally Red Crescent delegation was given permission named "ausgang" to approach the port by a German team of a Colonel, a Lieutenant and 20 armed soldiers. The soldiers, as they did in all their controls within 5 years, controlled each point of the ship, compiled, and collected all the files, papers, magazines and all the newspapers on the ship taking a very close examination so as to find out "something harmful".

After completing their fisrt mission and turning back to Turkey, one of those two delegates of Red Crescent Society named Saim Umar prepared a detailed report about their first voyage to Greece (KGMA. K. No. 2603, D. No. 1941-1943/9-4.), and he expressed that approximately 1.200.000 Greek people were suffering from starvation, and their situation was too pitiful to be hidden because of the Nazi atrocities there. In accordance with Umar's statement, Greece had almost no rain within the last 6 months and the agriculture in the country was almost dead, and Greek people were trying to get some food on the streets in vain while the official authorities distributed the Greek people only 45-90 grams flour a day. As a result, high inflation, and the black market spread all over the country and especially in the big cities such as Athens and Salonika. Thus, a loaf of bread was 800 drachmas, and the sugar was 1.200 drachmas for the people having almost no money to afford to buy.

Turkish Red Crescent delegations, at long last, came to Athens again using "ausgang" permission documents given by Kremer who was the chief of German Counter-Intelligence Department in Greece under the control of Nazi soldiers. Athens was completely very dark and darkened, and hundreds of people waited for the train in Piraeus-Athens train station damaged ground zero after the bombardments. Feridun Demokan finally came to Athinon Hotel in which German air forces personnel stayed in Athens, and he was "delivered" to the hotel personnel by German soldiers (KGMA. K. No. 2603, D. No. 1941- 
1943/9-4.). As soon as Turkish food assistance started being deployed to Piraeus brought by the Turkish ship named Kurtuluş, General Cholakoghlu made an explanation on behalf of his government and expressed Greek appreciation for Turkey (KGMA. K. No. 2603, D. No. 1941-1943/9-4.) In addition to all the food stuffs, the assistance packages of Red Cross Society, Balkan Medical Union, and Greek people living in Turkey were also taken to Greece (Red Crescent, February 1942; 8). The election of the suitable personnel for the Red Crescent mission was a very subtle situation due to the war, and a good many precautions were also taken about the regulations and the principles especially on the way to Greece. Red Crescent delegations were warned not to make interviews with the journalists and the media, not to accept extra and unknown stuffs, and they were also warned to make their all negotiations officially, and to take care of the ship, their landing in Piraeus, and their behaviors towards the captain and the crew aboard.

The situation in Greece was so terrific that lots of Greek people living in Piraeus rushed towards the port as soon as the ship named Kurtuluş anchored there. The humanitarian aid boxes supplied by Turkey were immediately loaded on the trucks and spread over the country. Greek people suffering from the starvation for a long period were at long last very happy and so as to show their appreciation, they prepared a painting of the ship and they expressed that the painting would be exhibited on the most beautiful spot of the city, adding that Greek people would never forget Turkish assistance and Turkish good will (Vatan, 25 $5^{\text {th }}$ October 1941). Similarly, numerous war-torn and war-shaken amputees in the streets begging for something to eat in almost every point of country were a natural and ordinary scene unsurprisingly (Rowland, 2000; 42);

"...As dawn approached, I went to wake my mother to remind her that it was time to go for our meager bread ration but was stopped by my sister. She said it was best to leave mother as she was very ill. Not realizing that my sister also was in no fit state to go anywhere, I asked her to come with me to collect the bread. She tried hard to stand on her feet but, was so weak from lack of food that she fell back down again... I quickly realized that my mother was in a similar situation to my sister so I broke off our bread ration and tried to force some of it into her mouth, thinking that might revive her but it was useless, I was fighting a loosing battle..."

On the other hand, Feridun Demokan staying in a hotel in Athens was always taken into custody and was monitored by German military forces and a Ger- man intelligence service team. When Demokan wanted to leave the hotel and to take a tour in the streets, he was always accompanied by an SS officer named Egon Kondumas whose father was a Greek, and whose mother was a German, and Kondumas knew Greek and English languages as well as speaking French (KGMA. K. No. 2603, D. No. 1941- 1943/9-4). To accompany Feridun Demokan in fact was nothing but, as expressed by Feridun Demokan, to keep close eye on his shoulder. In addition to all these hardships, Demokan got something good luckily, and Mr. Zanas allocated his private car for Demokan in Athens and Piraeus. The car Demokan used when he was in Greece was assigned by Greek Red Cross President Zanas regarding that Demokan's mission was very exhausting and tiring. Visiting Turkish consulate in Piraeus, Feridun Demokan saw that the building was destroyed by German bombardment, and he also noticed that all the Turkish personnel stayed in Turkish embassy residence in Athens with Turkish consul I.C. Özkaya (KGMA. K. No. 2603, D. No. 1941-1943/9-4). That Turkish consul told Demokan that he was a staff officer and that he fought with German forces during WWI and that Özkaya was blindly a German friend would make Demokan very sorry in the following days. The Red Crescent delegate Demokan on the other hand tried to learn something extra while carrying out his own ordinary but dangerous mission in Greece and all he wanted to do was to get rid of German officer, but his shadow as expressed by Demokan, did not leave him even for a second, and Demokan was unable to locate his Greek journalist friends so as to get the detailed news about the country (KGMA. K. No. 2603, D. No. 1941- 1943/9-4).

Soon after he came back to Turkey, Feridun Demokan presented his reports about Greece under German invasion and starvation to the Red Crescent Society Directorate but he noticed that Turkish Red Crescent President Rana Tarhan was not as positive as himself because Tarhan was very cautious and reluctant to take risks not to annoy Germans (KGMA. K. No. 2603, D. No. 1941- 1943/9-4). Rana Tarhan actually didn't want Turkish humanitarian aids to be blocked and to be stopped by Germans, and he didn't approve anything Feridun Demokan initiated in Greece as Demokan stated; "He was the person burdening the honor and the responsibility of Red Crescent Society. I, on the other hand, was called for the duty temporarily, and it was me who witnessed what happened in Greece, not himself. Therefore, it was almost impossible for both of us to share and to have the same thoughts. I was getting confused a lot." Having stayed in Ankara for 6 days more, Demokan turned back to 
Istanbul to monitor the cargo for Kurtuluş (KGMA. K. No. 2603, D. No. 1941- 1943/9-4).

The ship started its second journey with a cargo of bean, rice, 200 tons of chickpea, 1900 barrels of lonito, 3075 packages of lentil, 5 tons of sugar, 114 kilos of salted fish, 100 tons of bean, 1500 tons of dried broad bean, 350 barrels of bean, 304 kilos of onions, 51 tons of grape and fig, 1.500 .000 eggs, and 4 tons of rice and lentil flour valued 4800 liras (Red Crescent, 2-1941;21), and 22 boxes for Turkish embassy (KGMA. K. No. 2603, D. No. 1941- 1943/9-4) in addition to Italian and Greek Red Cross authorities in $28^{\text {th }}$ October (Vatan, 28 ${ }^{\text {th }}$ October 1941) and turned back to Izmir on 16, November 1941 (Vatan, $8^{\text {th }}$ November 1941). The ship also took totally 70 tons of unidentified and unknown stuff to Greece on behalf of Red Cross authorities in Greece to be delivered to 115 British prisoners of war in Greece (KGMA. K. No. 2603, D. No. 19411943/9-4). Witnessing the actual tragedy in Greece as the authorized and confused personnel, Feridun Demokan came back to Greece again. The terrific situation in Greece got worse and worse in such very hard winter conditions. The dead bodies in the streets were burdened and carried by the wheelbarrows, and the dead bodies with no sheet over created a terrific scene for the daily life in Athens having the most terrific winter within the last 50 years. Needless to say, local authorities on the other hand were all unable unfortunately to take care of the corpses, ignoring them in the streets for a long time. Witnessing the same terrific scenes all day long made Demokan very upset and sleepless at nights. All he wanted to do was, at all cost, to declare the outer world the tragedy Greece was suffering at that time, but who was going to help him? The ship personnel was also confused and upset when the ship approached the port in Piraeus (Vatan, $8^{\text {th }}$ November 1941);

"When landing in Piraeus I was between those who were at the dead's door. The skeletons take tours around. I have some relatives in Athens. They had a request from me saying'next time please bring us a picture of a wonderful banquet. Let's hang it on the wall of the shop so that everybody will see the meal even if it was a picture. Let them remember that the world was not only a hell but also a heaven. Cost of life was very high, and no food. The people are very terrific due to the starvation. The people in Athens say 'Did you get anything to eat?' instead of 'Good morning.' The captain of Kurtuluş says 'Give all the food in the ship to those starvation-suffered Greek people. We can anyway live with the water and the ship biscuits for two days.' In turning back to Turkey, the ship has to stop in Çanakkale due to the storm and the ship crew mur- murs saying 'What a pity! The Greek people in starvation are all waiting for us again."

According to Kurtuluş's crew, Azrael took off his masque in Greece and landed near the people fearlessly using his sickle mercilessly (Vatan, 20 November 1941). Kurtuluş, in its third tour to Greece, brought 298 tons of onions, 162 tons of potatoes, 582 tons of chickpea, 393 tons of bean, 80 tons of eggs, 90 barrels of salted fish, and two assortments of aid stuff departing from Istanbul on 24, November 1941 Monday, and the ship anchored at Piraeus port on 26, November 1941 Wednesday. Feridun Demokan, on the other hand, expressed that all these assistance activities were nothing but just an emergency aid for an injured person in the emergency service, and he determined to convey the tragedy in Greece, at all cost, to the USA so as to get extra help from that country, but he couldn't help expressing his feelings saying "I just saw the restrictions of the most authorized persons and the posts frankly."

The ship carried 428 tons of beans, 812 tons of chickpea, 180 tons of onion, 300 tons of potato, 60 tons of lonito, 300 boxes of eggs, and 650 packages of cloth as well as medical equipment in its $4^{\text {th }}$ tour to Greece (Red Crescent, 3-1942; 18). The former National Economy Minister of Greece visited Feridun Demokan and stated that some 500.000 people in need had something to eat by means of the facilities named Soupe Populaire (KGMA. K. No. 2603, D. No. 1941- 1943/9-4) which were donated by Kurtuluş and the death of the hunger people gradually started decreasing. The Greek Minister also added that the donations and the charity food were better than those which were brought from Turkey before, and the complaints also started decreasing, and he also added that Turkish charity efforts would never be forgotten in Greece (BCA. 17th. January 1942; 29730/30). In turn, Feridun Demokan stated that all the complaints about the food quality would be taken into consideration seriously and the necessary precautions would be taken at once (KGMA. K. No. 2603, D. No. 1941- 1943/9-4). Despite the fact that Turkish humanity assistance activities continued with no interruption, Demokan had some different and secret purposes so as to help the Greek people and to show what they were suffering from in Greece to the world public. To realize his plans, he started being closer to his Greek-origin German guide named Kondumas, and they started using Greek language mostly. Having seen that Kondumas relied on himself, Feridun Demokan frequently visited his Greek journalist friends alone leaving his German shadow in the hotel. All these visits would, in the near future, initiate his 
very hazardous plan to help Greek people. One of the persons Feridun Demokan visited in Athens was the Mayor of Athens; Angelos Georgatos. On the other hand, Feridun Demokan learned after the WWII that the Mayor had a very close, secret, and mysterious cooperation with British intelligent agency, and this situation surprised him a lot. On the other hand, the authorized personnel from both Greece and the Red Cross Society did nothing to help those poor Greek people, and all what they did was in fact to stand by doing nothing and Feridun Demokan was very eager, impatient, surprised, shocked, and angry to witness what was going around.

According to the news, Athens and Piraeus were nothing but the scene of hunger-w orn and dead people in spite of the Turkish assistance brought by Kurtuluş. Kurtuluş was just a symbol of salvation and survival for Greek people, and the Greek people established the picture of the ship in one of the biggest avenues in Piraeus as well as naming an avenue in Athens as Kurtuluş so as to show their appreciation (Vakit, 19 $9^{\text {th }}$ January 1942). Some Greek people, in addition, demanded that Kurtulus should be bought by Greek government as the unique souvenir of the tragical days in Greece. On the other hand, the United Kingdom having no responsibility in such terrific days stated that they themselves allowed Turkey to help Greece by Kurtuluş. Unfortunately the reality as known by the public was just the opposite, and British government started to consider lifting the sanctions and the embargo applied in the war area. The British government also stated that they looked for some new ways for the humanity stuff that would be transported to Greece, and their so-called hesitation was for the confiscation of the above-mentioned charity assistance by German forces (Ulus, $27^{\text {th }}$ January 1942).

Feridun Demokan, on the other hand, having got a special permission and tolerance from his SS guide, went on visiting his fellows and the journalists in Athens, and all what he wanted to do was to take the pictures of suffering Greek people and to take all those pictures out of the country immediately even if he didn't still know how to do such a risky action. Feridun Demokan's this initiation got the biggest support from one of the most influential and very experienced Greek journalist of Venizelos period in Greece named Manol Megalokonomou who had visited Turkey escorting Venizelos, knowing Ataturk well. Megalokonomou knowing how to take perfect photographs was also a man of confidence and reliability. In addition to this friend, President of Greek Journalist Association; Zarifis, Director of Press; Po- litis, Thomopoulos, and Drossos who was formerly minister in Greece were the other people who helped Feridun Demokan. Despite the fact that these above-mentioned journalists who were described as "my close friends, realizing his demands" by Demokan knew Demokan's thoughts, they were unaware of each other. They were all given the details of the subtle and risky plan, and they were stated to deliver the photographs they would supply in anyway to Greek Red Cross General Director Zevgolis secretly. Feridun Demokan had, similarly, very subtle plans of taking the tragical condition and disastrous life in Greece with the camera supplied by his friends, and delivering those photos to the Red Cross authorities.

While more than 400.000 Greek people consumed the food assistance from the facilities named Soupe Populaire as stated by the Greek Red Cross society, the people were out of hygienic conditions and cleaning as well as the vehicles due to the shortage of soap, cleaning stuff, gas and gasoline to use, causing the fatal epidemic. In addition, tramways, trucks, and the other vehicles were out of use because of the shortage of gas and coal for a long time. All the official facilities and the houses also suffered from the lack of coal with no electricity but with very cold weather. While Greek people especially living in the big cities suffered from starvation, and got almost no bread to eat, and a few restaurants serving only to the foreigners in Greece with very low-quality but with very expensive food couldn't also stand against the shortages and closed down. Unfortunately, Greek doctors making urgent operations in the hospitals all carried out those operations wearing very stick cloths since there was no electricity in the cities. Because Greece was experiencing coldest weather of the last 25 years, on the other hand, the rate of those who died from the cold weather was doubled those who starved to death in the relatively hot cities (KGMA. K. No. 2603, D. No. 1941-1943/9-4).

On the other hand, International Red Cross personnel working in Athens were all threatened by German military authorities and two Red Cross personnel working in Athens for months had prepared no real reports and sent no pictures showing the terrific conditions in the country. Unfortunately those above-mentioned Red Cross workers living in Kolonaki District of Athens, being very distinguished for its aristocratic and luxurious life, with the servants, hired cars and with their super salaries had never ignored German General Altenburg's severe orders not to inform and not to take photographs in Athens. In contrary to such a life, the hospitals, orphanages, the houses and the streets were all full of the dead bo- 
dies decaying alone. The cargo ship named Kurtuluş carried out its 5th tour to Greece on 14, January 1942 (Ikdam, $15^{\text {th }}$ January 1942) transporting humanity stuff as well as the swine hunted in Anatolia (Ikdam, $16^{\text {th }}$ January 1942). In Greece which was the home of the hunger bodies and the dead people, all the daily needs such as the match, flour, and bread were sold and distributed with the carnet (Vatan, $20^{\text {th }}$ November 1941). The highest proportion of those who died in the streets due to the starvation was women, children and the old people who put up a tremendous struggle to survive starvation.

The fact that German invasion forces in Greece freely confiscated whatever they wanted and that they tried to do everything officially caused a new turmoil. German authorities also started using newly published fake banknotes in Greece, and Italians and Bulgarians also took part in this new illegal system with their Mediterranean Drachmas, and Leva. Therefore in Greece, German, Italian, and Bulgarian currencies abruptly turned to be the chief currency. Moreover, German military command issued special occupational banknotes and distributed them freely without any limits to all the military units in accordance with their needs. Such banknotes with no value and prestige introduced by Germans covered all the country and unavoidably caused high rocketing inflation and deteriorated the economy at all. At last, the prices rose steadily, fuelled by the money printed to cover the demands of the occupation authorities. Inflation, similarly, led producers and retailers to withdraw their goods from the market, and hoarding became widespread. The country just turned to be a very dreadful nightmare scene that no money was used for shopping but for striking a match so as to light the cigarettes. Even if the government tried to collect foodstuffs from the farms to feed the starving people, and the government assigned some people to collect the produce, they sabotaged the government's efforts to collect grain as an act of resistance. Some farmers, on the other hand, refused to deliver their crop to the official authorities with intense hostility as in the vital grain-producing areas of the country. Thus, monetary system and the international trade were brought to a halt with food shortages and tragic consequences. Such an atmosphere of the crisis was made use of mostly by the debtors, farmers, wholesale businessmen and the black market dealers in some extent. Unlikely, the estate-holders, and those who had a certain financial profit, wage or salary turned to be the losers surprisingly. Greece where no money was seen and where shopping was realized with no money turned to be a stock market led by the rela- ted gossips. Greek people never believed the value of the papers named "banknote or the money", and started not using money for shopping. Therefore, for example, cigarette in Volos, olive oil in the mountainous areas of the country, grain in the fields started to be used as valuable things instead of the money (Ulus, $16^{\text {th }}$ January 1942).

The situation in Greece was so tragical that the children were completely busy within the trashboxes and the dumping grounds so as to get a piece of bread or a bone to bite, and the poor people all waited in the lines to be served soup when no bread or soup was distributed at all, and bread ration dropped drastically starting from 300 grams daily to 200 grams, and 30 grams eventually (Ikdam, $22^{\text {nd }}$ January 1942). In the following days, there were almost no bread and no soup while its quality was deteriorated as well (ikdam, $22^{\text {nd }}$ January 1942). The days passed by, and noticeably the problems, the stress, and the famine were to be felt a lot. Soup kitchens were set up in the streets to distribute the food-stuffs for the starving people and they were all run by the volunteer people, most of whom were the women and the nuns, and they had very strict rules and restrictions because there was only enough food for the children and the disabled persons not for the parents.

Kurtuluş sailing between Istanbul and Piraeus in October 1941 started the 6th tour on 18, January 1942 with its 36 personnel (KGMA. K. No. 2603, D. No. 1941- 1943/9-4) carrying some 1800 tons of food with primarily lonito, onion, and bean, thousands of charity boxes donated by Turkish citizens from different cities of the country, and 350 packages each of which was 5 kilograms donated by Turkish journalists for their colleagues in Greece as well as the total income of traditional annual Turkish Press Unity ball in Istanbul (KGMA. K. No. 2603, D. No. 1941- 1943/9-4). Unfortunately the 6 th tour turned to be the last tour of the ship and due to the foggy weather (KGMA. K. No. 2603, D. No. 1941- 1943/9-4) in the vicinity of Marmara Island off Marmara Sea (Ulus, $21^{\text {st }}$ January 1942) causing a terrific shipwreck (Ikdam, $21^{\text {st }}$ January 1942) it demolished "the set which was prepared to keep more than 500.000 Greek people away from death" in Athens and Piraeus (Vakit, 19 ${ }^{\text {th }}$ February 1942). Demokan stated the ship wreckage as a disaster after he survived the tragedy. The ship was unfortunately capsized within 5 hours and Demokan together with the ship crew watched everything bursting into tears. The survivors got a small boat luckily and climbed up a cliff in the midst of the sea. All what Feridun Demokan could save was a diplomatic pouch, Red Crescent file, and his camera (KGMA, Feri- 
dun Demokan Private (Diary) Archive);

“...In our $6^{\text {th }}$ tour, a terrific disaster occurred. In $18^{\text {th }}$ January 1942 in the evening and in a windy weather, Kurtuluş crashed into the cliffs off Marmara Island, not resisting against the wind blowing from the north. We have watched how tons of assistance stuff was sunken into the debt of the sea on the cliff we have climbed up in difficulty, bursting into tears... While the people in Athens were mourning for Kurtuluş, Turkish Prime Minister Şükrü Saraçoğlu informed that the government had allocated a bigger ship to carry the humanistic stuff to Greece named Dumlupınar..."

Thus Kurtuluş happened to be a historical reminiscent as the symbol of Turkish charity and assistance to Greece and 50 years after this assistance activities, a ceremony was held at Dolmabahçe Palace where the first tour of the ship was launched, and some speeches were made with the participation of some people such as Greek author Andrew Politakis who was the founder of Abdi İpekçi Peace and Friendship Reward Association, Greek author Prof. Dr. Dimitri Kitsikis who was the writer of "Greek Propaganda", The President of Turkish-Greek Friendship Association; Ord. Prof. Dr. late Ekrem Akurgal, the Former Mayor of Istanbul; Bedrettin Dalan, businessman Şarık Tara (Hürriyet, $2^{\text {nd }}$ February 1992).

\section{6-THE SHIP NAMED AFTER KURTULUŞ}

While the people living in Athens mourned after Kurtuluş, the first initiations to rent the ship named Tunç came to an end with failure, and finally a new ship named Dumlupınar was rented by Turkish government and the cargo of medical and food stuff got prepared to burden on the ship. The first cargo of the ship contained 300 tons of potatoes, 158 tons of salted and dried fish, 100 tons of figs, 200 boxes of eggs, 3560 kilograms of swine meat, some 300 tons of beans (KGMA. K. No. 2599, D. No. 1942/9-4) and 500 pairs of stockings in addition to the 600 tons of charity stuff donated by municipality personnel (Ulus, $19^{\text {th }}$ February 1942) with the charity stuff donated by Turkish journalists, and the ship completed its first duty 12 days later in the period of $21^{\text {st }}$ February- $7^{\text {th }}$ March 1942 in Istanbul. Another cargo ship named Konya, meanwhile, also departed to Piraeus carrying 549. 308 Turkish liras donated by Turkish people, medical stuff, 5 tons of soup, cloth and a variety of assistance (BCA.030.10.169.176.29). Helplessly feeling the shock of the occupation as well as famine, Greek people waited for the savior from Turkey named Dumlupınar. On the other hand, German Nazi pressure upon Greek Red Cross authorities got heavier and heavier in time and German military forces kept very close eye on Feridun Demokan as well, learning all what he did when he turned back to Istanbul, and with whom he met in Istanbul. In addition to ongoing assisting activities in the last one year, various news in relation to Greece were released in Turkey and these news caused German intelligence services to carry out stricter and more serious actions. Feridun Demokan on the other hand considered that he should do something promptly.

A new ship after Kurtuluş's wreck was welcomed by International Red Cross Assembly, Greek Red Cross, German and Italian representatives of the Red Cross, and Athens - Piraeus chief consul as well as Greek people residing in that region. As it was too late to leave the board after the completion of the controls and bureaucratic transactions by the German occupation forces, the Red Crescent Assembly could also not leave the ship but only could step on land on the next day. As the fuel oil bases and live transport vehicles were not available during the cargo unloading from the ship only the human labor was employed, and since the people in the region were very weak ${ }^{63}$, the discharge was extremely slow and ineffective. German occupation forces and the Red Cross representatives were warned by Red Crescent delegates that this would result in greater obstructions if not prevented, and that in order to take the relevant measures, and that the ship would raise anchor immediately after the relief materials were discharged on the pier announced.

Greek Red Cross authorities, however, were aware that Greece was an unsecure country because of severe famine and the occupation, and if the charity stuffs were freely discharged in the pier then the Greece people would attack upon the materials and this couldn't be prevented. International Red Cross authorities were applied for this challenge and it was requested that the departure date of the ship should be delayed. Dumlupınar ship crew were reluctant to breach the written order by the Coast Guard Command of Istanbul City as "the back freight date of the ship shall be declared to you additionally when arrived at Piraeus" and the ship crew did not know how to forward this declaration to the command as the communication between Turkey and Greece was not now available. However, such an order was never released. Upon the onset of the discharge of assistance materials from the ship, the rain got heavier, it was rainy so much that it was not possible even to work on the ship on 1, March 1942 and it was also not possible to open the covers of the stocks of the ship (KGMA. K. 
No. 2599, D. No. 1942/9-4) and the ship came back on 7, March 1942 by 14.30 hrs and anchored before Kabatas District.

Meanwhile, it was on the agenda that out of the reported approximately 3.500 Turks in Greece, the ones whose "the most urgent need is assistance" (KGMA. K. No. 2599, D. No. 1942/9-4) should be gradually brought to Turkey and this was discussed with the German and Italian occupation forces as well as the discussion with the Greek Red Cross authorities. At this point, both German and Italian Red Cross authorities, the delegate of Red Crescent, Feridun Demokan, the captain of Dumlupınar and the other delegate of Red Crescent Saim I. Umar considered differently upon this matter and presented their various opinions on the matter related to bringing Turkish subject residing in Greece by Dumlupınar to Istanbul. On the other hand, Saim I. Umar notified that it was very hazardous because of the mission of the ship and he considered that it wasn't appropriate to transport people on Dumlupınar. Saim I. Umar and the fixed minded Consul General of Turkey to Athens - Piraeus, and two daughters of the Greek wife of Muharrem Denizalti and Resmiye Dino registered in the extract of an Albanian family; submitted a special permission (KGMA. K. No. 2599, D. No. 1942/9-4) for the transportation of these people by the ship to Turkey and he requested that the appropriate Turkish people should be brought to Istanbul. 14 people who were entitled by the special permission of the Counsel General in this direction arrived at the pier before the departure of the ship with their personal passports, and they had also their passports certified by the Italian and German authorities. Those 14 people having reached out the ship were subjected to the control of the German marine officials in an environment in which the Turkish Council General before Athens Piraeus was standing and after long transactions and time loss in total 6 people were given permission to be on board. The remaining 8 people stepped to the pier being carried by the boats (KGMA. K. No. 2599, D. No. 1942/9-4). These 6 people did not pay for any expenses but paid only for the meals. The ship crew who obtained the required information and order from the Athens General Consulate considered that "this order is released by the high Consul" and brought those persons to Istanbul by the ship. On the other hand, the ship crew was under the very hard circumstances as the GD for Red Crescent notified its staff that the orders by the Foreign Affairs Minister should be declared by themselves. In addition to these, GD for Red Crescent declared that they should be notified as a result of the requests from dif- ferent countries and different authorities related to the transportation of the people, and it also declared that it should be transacted from now on (KGMA. K. No. 2599, D. No. 1942/9-4). As well as the assistance materials by the Red Crescent to Greece, the first Turkish health staff was forwarded for health assistance (KGMA. K. No. 2660, D. No. 1945-1953/9-4). Meanwhile, the condition in the country was worsened by the German invasion, starvation, winter conditions and epidemic diseases (Ulus, $14^{\text {th }}$ February 1942).

\section{7- DUMLUPINAR'S SECOND JOURNEY TO GREECE}

The second travel (KGMA. K. No. 2599, D. No. 1942/9-4) of Dumlupınar started on 25, March 1942, on Wednesday by 17:00 hrs and finished in the Piraeus pier on 27, March 1942, on Friday at 14:00 hrs, and the assistance material on the board included: 400 tons of figs divided into 30.905 small bags, 350 tons of beans divided into 3.383 jug packs, 1.004 tons of haricot beans, 261 tons of olives divided into 2.526 baskets, 350 tons of olives, 50 tons of eggs and 50 tons of fruits divided into 500 trunks, 20 tons of salty swine meat divided into 225 trunks, 23 tons of pork divided into 225 trunks, 6.5 tons of various food stuff divided into 440 boxes, and 5 barrels of sardine, and 32 jug bags of blankets (KGMA. K. No. 2599, D. No. 1942/9-4). By the way, 7.000 tons of wheat and 13.000 tons of corns and panicum were collected and distributed to the society. As performed in the previous travels, the German authorities came on board and did the required controls and they notified that only the Red Crescent delegates and Saim I. Umar and Feridun Demokan could step on land. Feridun Demokan could step on land while Saim I. Umar stood on the board as there were not enough vehicles. Whilst the Red Crescent representatives and Saim I. Umar and captain of the ship were sitting on the board together with the German officials, the four titanic ships of German origin which they were aware in the future that they were full of arms and costs anchors. Ship crew was sleepy and concerned by taking some measurements required for their safety. After anchoring in the morning, the Red Crescent representatives came to Athens under surveillance of Gestapo and with the escort of Athens - Piraeus General Consular and they visited the President of Greek Red Cross, Mr. M. Atanasakis and the letter related to 500 blankets sent by the Red Crescent was delivered. The Board additionally visited the representatives of International Red Cross Foundation. Due to Easter in the regions of Athens and Piraeus, the former 50 dir- 
hams of food distribution was raised to 80 dirhams. In such a period in which many people were homeless, and many were forced to beg for food or even to steal a piece of bread from Germans, or whereever they could do so (Yeni Asır, $5^{\text {th }}$ February 1942), Dumlupınar was welcome with such a great cheer and love in Piraeus that Greek people called the Turkish sailors 'Second Hristo (God)' (Vakit, $9^{\text {th }}$ March 1942).

\section{8-THE THIRD JOURNEY OF DUMLUPINAR}

The third travel of Dumlupınar ship started from Istanbul pier on 24, April 1942, on Friday, at $13.00 \mathrm{hrs}$ (KGMA. K. No. 2599, D. No. 1942/9-4). In this travel, the ship carried 1.000 tons of dry figs, 57.510 tons of apples, 26.970 tons of chestnuts, 429.915 tons of olives, 150 tons of eggs, 26.787 tons of lonitos, 4 tons of salty grey mullets, 15.311 tons of salty sardines, 5.150 tons of swine meat, 395.853 tons of haricot beans, 270 boxes of various food stuff for the Greek MP's and 310 boxes and 46 jug bags of various food stuff for the Turkish people, and also 6 boxes (KGMA. K. No. 2599 D. No. 1942/9-4), and 59 jug bags of various food stuff and 10 trunks of eateries (KGMA. K. No. 2599, D. No. 1942/9-4).These stuffs were reported to arrive in Piraeus pier and the stuff was discharged (Ulus, 29th April 1942).Feridun Demokan also made a decision to act in this ninth travel to Greece, and he started implementing his plan known as "Great Gambling". Accordingly, two similar photo albums including the photos which were taken and obtained by various forms secretly, demonstrating the bad conditions of Greece and Great Famine Period were ready. Feridun Demokan considered throwing away those photo albums before the eyes of German Command Kremer, and his assistant Lieutenant Benzen and his so-called director of Kondoumas and he intended to do this at all costs. Meanwhile, the Greek Red Cross hospital constructed by the Greek rich people in 1930 in Athens was also visited by the Turkish Red Crescent personnel. The hospital which had the departments of surgery, internal diseases, and eye diseases with 240 bed capacity was turned to be a hospital with 420 bed capacity by treating the patients even in the corridors of the hospital. The roses around the hospital which was located "in the middle of an elegant and beautiful park" were taken off and potatoes were cultivated instead. The patient rooms in the hospital were also visited by the Red Crescent delegates and the rooms in which the Greek soldiers who lost their various extremities during Greek - Italian war were particularly visited. As the patients who knew Turkish in an advanced level had requests to meet the Turkish delegates, the complaints of the patients were listened in a suitable time where the hospital director and other authorities were also present. The patients expressed that the eateries sent by their "high minded Turkish Neighbor" were not given to themselves, and as they were fed with bean and chick pea soups unsatisfactorily, they were gradually weakened and were healed late, and that the charity materials delivered to the country were marketed by the secret persons "underhandedly" or consumed and devoted by the administrators of this assistance and then the Red Crescent delegates met the issue with the Greek authorities as they did not want to intervene in the sovereignty of Greece. This great food depression was reported to be lived throughout the world by the Red Crescent representatives and then they took a souvenir photo with all the patients. The Greek officials had trouble with the complaints of the patients before the officials in Turkish and with the patients' request to take a photo with the Turkish officials, and they couldn't still prevent this. During this visit, based upon the permission by the British Ambassador for Feridun Demokan, a biscuit box of $25 \mathrm{~kg}$ for the 78 injured officers and soldiers, and 2 trunks of meat divided into 96 jars, and $56 \mathrm{~kg}$ figs and $50 \mathrm{~kg}$ raisin were delivered and the photos were retaken. The school of nursing care which was located in the same premise was also visited during the hospital visit and the nurses who were graduated from Florence Nightingale Nursing Care School as Turkish nurses Fatma Bengisu and Fatma Acar were graduated.

During this third travel of the ship, an air attack by the English aircraft was done and the arounds of Athens and Piraeus pier were under bombardment on 29, April 1942 approximately at 01:00 pm, and four shops and a house which were 800 meters away from the point where Dumlupınar was anchored were destroyed (KGMA. K. No. 2599, D. No. 1942/9-4). The Red Crescent representatives Saim I. Umar and Feridun Demokan also visited the Greek Red Cross First Aid Center located at the Omonya Square of Athens. This center which attracted and appalled the Red Crescent representatives was a kind of first class center (KGMA. K. No. 2599, D. No. 1942/9-4) of which little equivalent was desired to be established "in our country at least in Istanbul or Izmir" as expressed by Feridun Demokan (KGMA. K. No. 2599, D. No. 1942/9-4). Two young Greek women whose feet were injured by the German military lorry as well as three Greek people who fainted of starvation were also urgently hospitalized and were brought to the center during their visit. As done in the previous period, Red Crescent representatives also visited the General Consular to Athens - Piraeus (KGMA. K. No. 
2599, D. No. 1942/9-4). Yet, Feridun Demokan's major reason to visit the Turkish General Consulate in Piraeus was to bring two big-sized envelopes including the photos to be transferred to Turkey as a diplomatic courier accurately (KGMA.Feridun Demokan Private (Diary) Archive). Demokan intentionally extended the visit to Turkish General Consular named Ragib Bigat, and he requested from the Turkish General Consular to continue the meeting on the board, and then they went to the board together (KGMA.Feridun Demokan Private (Diary) Archive). The envelope including the photos was sealed with red wax stamp, and was left in the front site of the vehicle by the driver of the consular, Niko. Nevertheless doubtlessly Niko was unaware of the content of that envelope. The car went fast through Singrou Boulevard which was solely used by the military vehicles and they reached out to Piraeus pier (KGMA. K. No. 2599, D. No. 1942/9-4), and Feridun Demokan and Turkish General Consular to Piraeus immediately went on board. In this time, German control assembly was also on the board and the ship shall from top to bottom be detected. Feridun Demokan left two diplomatic courier envelopes including the photographs on the table in the hall (KGMA.Feridun Demokan Private (Diary) Archive).

The soldiers detected each point of the ship with the order of German Commander Kremer and detected Feridun Demokan's room to the slightest detail. During this detection, Turkish General Consular and Feridun Demokan seemed fairly relaxed and they shared a bottle of cognac, a bar of chocolate and a box of cigarettes with the German Commander. In fact, this was an anxious and tedious suspense, but only Feridun Demokan was aware of the fact. The atmosphere in the hall at that moment with the words of Demokan "was so soft and quiet that Commander Kremer couldn't examine the two great envelopes entangled in my document bag onto the table close to us." Afterwards, the Commander Kremer stood up and everybody saw of them, and asked kindly Feridun Demokan for his next travel to accept the coffee to be given by the Commander's old mother living in Dantzig and then Dumlupınar under the control of the captain Vedat Kocaaslan left Piraeus. Feridun Demokan was the winner of the "great gambling". The possibility of losing the gambling and the possibility of the Germans to find the photos and the possible events related to these possibilities were of scary scenes and if these photos were found by the Germans, it was doubtlessly true that the Germans would take them to the popular camps close to the Black Forest. Following his return to Istanbul with the extremely danger and significant beings, Feridun Demokan kept one of the albums for himself and received the other album to Colonel Gibson from English intelligence service in order to be delivered to the US authorities in a dinner environment where the journalist Ahmet Emin Yalman, and English diplomat De Chastelain and M. Fox and so-called English journalist but the director of Britain News Agency Mc. Kintosh were existing. The President of Red Crescent Mr. R. Tarhan did not want to take responsibility for this condition and burdened the entire project on Feridun Demokan's shoulder saying nothing about how to use the photographs to Feridun Demokan. Nevertheless these photographs were sent to Washington through London and some of them were published in the magazine called Life dated $2^{\text {nd }}$ August 1942, thereby enabling millions of people throughout the world to see the events in Greece.

\section{9-THE FOURTH JOURNEY OF DUMLUPINAR}

The fourth travel of Dumlupınar ship was carried out on $7-8$, June 1942 starting from Izmir, and in this travel the ship included 20.000 jug bags of raisin, 3385 jug bags of figs, 19199 trunks of figs, 1626 jug bags of nutmeat, 2665 barrels of salty lonitos, 46 barrels of salty gray mullet fish, 995 trunks of crushed walnut, 100 trunks of eggs, 2731 baskets of olives, 23 trunks of swine meat, up to 200 jug bags of various food stuff (KGMA. K. No. 2599, D. No. 1942/9-4) and discharged these materials to the Piraeus pier and the ship came back home one week later (BCA.030.10.169.176.29). Most of the salty fishes which were brought in the fourth travel were unfortunately spoilt (KGMA. K. No. 2599, D. No. 1942/9-4). In addition, it was expressed by the ship agency operating in Piraeus that some boxes were absent and the five kilogram boxes sent from Turkey were controlled by the German control assembly and stocked on storage in order to be treated (KGMA. K. No. 2599, D. No. 1942/9-4). The fifth travel of Dumlupınar ship was carried out on 19, July 1942 at approximately 15.00 starting from Canakkale pier (BCA.030.10.169.176.37) and the ship finished the mission on 22, July 1942 in Piraeus pier. The ship carried 4912 jug bags of figs, 5280 jug bags of rassin, 5037 trunks of rassin, 8625 jug bags of nutmeat, 1316 trunks of crushed walnut, 523 trunks of mackerel, 1943 barrels of anchovy, 100 barrels of sardine, 77 trunks of various medical materials, 18 jug bags of shoes, 18 trunks of drinks, 3 trunks of cigarette, 89 trunks, jug bags and bundles of various food stuff (KGMA. K. No. 2599, D. No. 1942/9-4), and after the discharge, the ship came back to Istanbul (Ikdam, 16 July 1942). The air attack by the English aircraft after 
a 43-day of interval restarted and continued for 1.5 hours around Athens and Piraeus on 11, June 1942 but the ship was not directly damaged, yet the pier on which the ship was anchored was bombed 1 day before that day, and the Swedish Red Cross ships just near Dumlupınar were exposured to bombardment (KGMA. K. No. 2599, D. No. 1942/9-4). Singer Sewing Machines Co. and Nordstern Insurance Co. respectively sent 14 and 50 boxes of food stuff by this ship. Additionally, 370 boxes of medical materials were sent, and 800 boxes in total were sent to Greece (KGMA. K. No. 2599, D. No. 1942/9-4).

In this travel, 12 boxes by Turing Corporation, 50 boxes by School of Senior Engineers, 36 boxes by Ottoman Bank, 1800 boxes by the chamber of physicians, 40 boxes by Anatolian Agency, and 24 boxes of $12.5 \mathrm{~kg}$ by Press Union and 300 boxes of food stuff by the Turkish people to their relatives in Greece were sent (KGMA. K. No. 2599, D. No. 1942/9-4). In addition, Turkish Union of Senior Engineers requested the permission for sending dried fruit, smoked fish or salted fish and swine meat to the Athens Union of Engineers. The same request was, later on, made by Balkans Union of Physicians President Akil Muhtar Ozden, and he notified that he intended to send 25 food packages of permitted boxes as a result of the request by Greece Assembly President Pr. Bensis for the friends and families in Greece, and he prepared 25 packages of five kilos (KGMA. K. No. 2599, D. No. 1942/9-4). Meanwhile, 198 boxes of food stuff were sent by Turkish people for their relatives in Greece.

The next travel of the ship was carried out on 22, August 1942 and the ship included 3180 baskets of olives, 240 trunks of mackerels, 751 trunks of sardine, 120 trunks of anchovy, 744 trunks of Spanish mackerel, 40000 trunks of rassin, 10286 jug bags of nutmeat, 4 bundles of cotton coats, 1 bundle of cotton scarf, and 66 jug bags of various food stuff and these materials were discharged into Piraeus pier (KGMA. K. No. 2599, D. No. 1942/9-4). In a research held in the year 1943 in Greece, it was stressed that state officials particularly in Athens, private sector workers, people in the small workplaces, lawyers, the persons receiving the monthly pension and small merchants mostly passed away (www. Historia. Su. Se/urbanhistory/eauh/papers/r2_bournova.Pdf.).

Starvation, extreme poverty converted the state officers, workers, authors, artists, cultural workers, lawyers into the news, cigarette, handkerchief, and street sellers of vegetables and small fruits collected from the hills. Even the Italian Ambassador to Greece was among the ones who sold out their home. As stated by Feridun Demokan, it was more than one year since the charity tours to Piraeus started and a lot of news had also been seized to Turkey about Greek tragedy. Meanwhile Feridun Demokan had supplied a photo album consisting of more than 120 pictures from Greek tragedy by the help of his close friends in Athens. Gestapo officers were very rude and the customs examinations were also very detailed as well as the bothering intelligence activities towards Red Crescent personnel (KGMA.Feridun Demokan Private (Diary) Archive). Not only Gestapo but also Feridun Demokan's special guard named Kondumas were very cautious and keeping their close eyes on Feridun Demokan. Kondumas and his some words with allusion showed that they were suspecting from Demokan and his activities in Athens. In this $9^{\text {th }}$, and the last tour, Feridun Demokan decided to play "a big gambling", and he would smuggle two similar photo albums in the very front of German officers like Commander Kremer, his vice-commander Lieutenant Benzen, and the special guide Kondumas. The plan was very hazardous, risky and unbearable to carry out but he had almost no chance except this one (KGMA.Feridun Demokan Private (Diary) Archive);

"Just before our departure to Istanbul, as I did so many times before, I went to say Good Bye to our Consulate and to Turkish embassy to get the diplomatic pouch. While sealing some diplomatic pouch with Turkish Ambassador Ragıb Bigat, We were talking about some directives for Turkish Ministry of Foreign Affairs. After I intentionally spent some more extra time there, looking at my watch, I said it was too late to prepare and to discuss the rest there, and I requested to go to the ship together. The ambassador accepted my offer and I gave my bag, diplomatic pouch, two albums in two similar and big envelopes to our old driver named Nico and I wanted him to put all these stuffs near himself in the car. Niko, driving the car with Turkish flag through Singrou Boulevard allocated only for the military vehicles very fast, and he brought us to the port. We came aboard the ship and went to the hall. German control delegation was there, waiting for me. Seeing the counselor with me, they understood why I was late. There was a long table with constant chairs for 15-16 persons in the hall of the ship. The crew brought my luggage and put in my cabinet having doors towards the hall. But l, putting my diplomatic pouch, the envelopes which were not certain whether they were sealed or not, and my bag in the midst of the table, I apologized for being late from Commander Kremer. I slowly ordered my servant Muzaffer to bring cognac, liqueur, chocolate, cigarette, etc to the table after the coffee service. The armed soldiers were spread everywhere and started 
the searches in the ship. As long as we drank and had something, the conversation turned to be sweeties in French..."

German command staff aboard were with Feridun Demokan and Turkish diplomatic staff of the embassy, and some comments about the end of the war with German victory made German officer very happy. The soldiers controlling each spot of the ship in detail sometimes came in the hall screaming 'Hail Hitler" and giving their reports to the commander (KGMA.Feridun Demokan Private (Diary) Archive). The soldiers finally came to Feridun Demokan's cabin and 3 soldiers entered the room in a rough and rude way, emptying all the wardrobes, and the luggage here and there. Minutes later they completed the duty and left the area giving their last report. The atmosphere in the hall as Feridun Demokan expressed was so soft that Commander Kremer was unaware of 2 big envelopes with a good many terrific photographs from Greece and he never wanted to behave in a rude way and to control all those envelopes there after such a sincere and soft gathering (KGMA.Feridun Demokan Private (Diary) Archive). Everybody in the hall stood up and after a very sincere good-bye and farewell ceremony German commander Kremer left the ship, requiring a pack of coffee for his mother from Feridun Demokan when he arrived in Istanbul (KGMA.Feridun Demokan Private (Diary) Archive). 30 minutes later, the ship led by Captain Vedat Kocaaslan left the port, escorted by 2 German warships, passed through torpedo lines, and anchored in Çanakkale hours later. Feridun Demokan years later stated the situation as followed (KGMA Feridun Demokan Private (Diary) Archive) "I had played a big gambling and won. If not, the turmoil, the chaos, the scandal that would contain Red Cross and Red Crescent, the abolishment of the agreements unilaterally, the restriction and the embargo upon the food and charity service of thousands of people would tremble me like an aspen leaf and frighten a lot. Moreover, the fact those German forces that would capture some important documents and the photographs I had hidden in the albums would take me to those very famous detention camps near the Black Forest. The following day, while our ship was coming closer to Çanakkale, I felt myself like a small kid who missed her mother, hugging her when he met with the mother."

Feridun Demokan kept one of those photo albums, and he delivered the other one to British Colonel named Gibson who was a diplomatic courier between Cairo, Ankara and London in a lunch party arranged at Istanbul Club a few days after his arrival in Istanbul. In this lunch party, Turkish journalist Ahmet Emin
Yalman of Vatan newspaper, De Chastelain from British Embassy, M. Fox, and Mc Kintosh were also ready (KGMA.Feridun Demokan Private (Diary) Archive). De Chastelain was in reality the man who was parachuted to Romain, prepared and got the plans of the petroleum lines there, and who was taken back by a small plane again, and he was well-known as the petroleum engineer who prepared the famous Ploesti bombardment. Mc Kintosh, on the other hand, seemed to be the director of a so-called British news agency named Britanova News Agency founded by British Intelligence Agency in Istanbul (KGMA.Feridun Demokan Private (Diary) Archive).

Then the album was transferred to the United States of America via British intelligence service. Having completed his mission, Feridun Demokan went to visit Chief of Red Crescent Society, Mr. Tarhan and he once more didn't want to assume the responsibility of the photographs and left Demokan free to do whatever Feridun Demokan wanted to do. Feridun Demokan expressed that when he was in 10th tour towards Greece, the photo album arrived in the USA from London safely. On the other hand, something was wrong here since Demokan had taken part totally in 9 tours to Greece. Millions of pictures showing the tragedy in Greece were printed and published firstly at Life magazine dated $2^{\text {nd }}$ August 1942 in two special pages. War Relief Society founded in the USA and led by Spyros Skouros being a movie maker who was mostly known by his charity activities made mostly use of these pictures and managed to gather more than 200 million dollars. It was a very beneficial situation for the War Relief Society to buy food and charity stuff for Greece during WWII period.

\section{0- POST WAR PROCESS}

After his mission finished, Feridun Demokan was awarded with an owl relief which was the symbol of Athens city and with a certificate of honorary nurse presenting the thankfulness and appreciation of the Athens citizens as stated by Demokan "No sooner had the new President of Red Cross expressed me the appreciation and the gratitude of Greek people in Red Cross building than I forgot all my pains I had suffered in the last 15 months." Having completed his hazardous mission, Feridun Demokan turned back home and went on working as a journalist, but Greek people never forgot him as shown in the newspaper named Acropolis dated 20th June 1942 (Interview performed by Greek journalist E. Thompoulop, Feridun Demokan Private Archive);

"This is the outstanding man Feridun Demokan, 
the man who delights in the thrills of a dangerous life- who traverses stretches of seas where the war is raiding, in order to diminish the difficulties of the food conditions in Greece. But such journalistic flagwaving is beneath Mr. Feridun Demokan's dignity. He does not like it, and it is neither appropriate to his character nor to his true purpose to which he was devoted himself entirely since last November. As I remember him the last time I saw him reclining on his veranda, gazing at the spectacle of the starlit sky of an Athenian night- I think I see in him a perfect embodiment of the words of the Koran; 'Perform your duty without thought of recompense."What is the extraordinary thing about it?' he tells me. 'I think that every Turk would have done the same as I do and every Greek would do the same to a Turk had he been in this difficult situation in which you are now.'And stroking his grey temples, he adds in good Greek, with a slight Turkish accent: 'I don't think you can disagree.

Any human being would have acted in the same way... I was recently at the Ministry of Finance at Ankara to obtain a permit for the export of food-stuffs which the Dumlupınar has again brought you. There were also applications for the export of food-stuffs to other countries When I came to the head of the department concerned, and I told him the purpose of my visit, he rose immediately and said to his assistant: 'Be quick and make out the papers Mr. Demokan needs. The other ones can wait. They are for foreign countries. Those for Greece are the most urgent. I cannot convey the exact tone in which these sentences were pronounced, but, you will understand from the way he emphasized the words 'foreign countries' and 'Greece' what this good Turk felt...' All in all, he has made eleven voyages to our country before being transferred from the Kurtuluş one late November afternoon as a herald of 'good tidings' with the first food-stuffs from Turkey. By now, his voyages including passages in stormy winter and the sinking of the Kurtuluş amount to twenty-five, and the twenty-sixth he hopes he will have been completed by the end of this month... His great love was Yanina, to which he was drawn by one particular reason, namely, the guardian angel and companion of foodstuffs from Turkey to our people originates from Greece. His father and mother come from Yanina, and there, too, is the house of his parents. The voice of his ancestors and memories of his parents have created an unquenchable love for our country and its people. His father, a general, despite his bad luck in having been taken prisoner by the Greek army, and his mother, had told him several times: 'Love the Greeks. We never felt there was anything which divided us from them. One day, the two peoples will become inseparable friends.'

With these principles, with this is what I would call instinctive love, it is not surprising that Mr. Feridun Demokan has, for the last eight months given up his personal leisure and family life- he has only been married a few months- in order to travel to and fro between Ankara, Istanbul and Piraeus, and to cross seas known for their storms and full of dangerous war-traps (mines, etc.), in order to bring us the foodstuffs sent by the Red Cross in cooperation with the Red Crescent. The very fact of his terrible experience when last January the Kurtuluş was sunk and he was found in the frozen waters of the Dardanelles and in danger of being drowned, and yet continued his mission with the Dumlupınar proves how noble, and imperturbable he is; a true altruist, he continues and will continue his noble mission as long as international agreements permit. Now we are afraid he will, in his modesty, be taken aback by what has been written here about him, just as he was by the unanimous decision of the Town Council of Athens to award him the honorary citizenship of the Capital. But just as Mr. Demokan states that he is only doing his duty, it is even more our duty to express our thanks and gratitude."

Similarly, the people living on the island named İstanköy (Kos) stated their honest feelings as explained by Elefterios Prokos on $27^{\text {th }}$ August 1943 as 'The city of Athens, the holy cradle of civilization and human grandeur, named you as their honorary citizen for your extraordinary services The Greek people, whom you served at the moments of his strife by bringing the victuals of the Red Crescent, when he was lead starving to the incessantly broadening newly dug graveyards, has expressed to you with emotion his gratitude. On the occasion of your arrival in Athens, with my present letter I wish to let you know how deep is the gratitude in the hearts of the population of Chios island, the poor classes of which will never forget what you have done fort hem. As a Greek and as a Prefect of the Greek state, I shake your hand with emotion and gratitude. In your person, Greece has acquired a new valuable friend.'

After WWII, he came to the USA as correspondent for the Turkish newspapers such as Tanin, Vatan, Turkish News Agency and Yeni İstanbul, and he was accredited as the United Nations Correspondent after 1949, being the member of United Nations Correspondent Association and Foreign Correspondent Association of New York, and Secretary of the AmericanTurkish Society of New York. Starting from 1946 up to 1948 , he has been economic advisor of a good many 
American firms including Byrne Associates (consulting engineering), $20^{\text {th }}$ Century Fox Film Corp, Prudential Steamship Corporation, etc. He was the permanent correspondent for the Turkish News Agency (USA and UN) after 1961. Feridun Demokan was accepted to be naturalized American citizen in 1964.

\section{1- CONCLUSION}

Greece was a country in which some 3.000 people a day lost their lives due to the starvation and famine during the WWII. Almost all the countries, unfortunately, just looked on and stood by what was happening in Greece instead of helping those unfortunate people in need. It was only Turkey which did all its best to help Greece, donating food, medical equipment, cloth, blankets, and everything Greek people might need. Turkish Red Crescent representative in Greece named Feridun Demokan, on the other hand, took the responsibility of charity activities, and tried to inform the public about the tragic situation in Greece, and endangered his own life. At long last he managed to perform a subtle and risky plan and the world was informed about the Grand Famine in Greece through his endeavors. Greek people and the government showed their appreciation by rewarding Feridun Demokan with an honorary medal and a certificate, and named the largest avenues in the country as Kurtuluş, and put the pictures of those charity ships on the walls.

\section{REFERENCES}

Armaoğlu, F. (2004) 20. Yüzyıl Siyasî Tarihi (1914 -1995), Istanbul, Alkım Yayıncilık.

BCA (Prime Ministry Republic Archive). 030.10.169.176.37

BCA.030.10.169.176.29

BCA.030.10.169.176.29

BCA.030.18.1.2.94.17.17.

BCA. The report written by Foreign Affairs Ministry to Prime Ministry dated 17th January 1942 numbered 29730/30.

Bilge, A. S.(1996) Ankara Atina Lefkoşe Ü̧̧eni, Ankara.

Deringil, S. (1994) Denge Oyunu; İkinci Dünya Savaşı̇nda Türkiyénin Dış Politikası, Istanbul.

Gürel, Ş. S. (1993) Türk-Yunan İlişkileri (1821-1993), Ankara.

Hatipoğlu, M. (1997) Yakın Tarihte Türkiye ve Yunanistan, 1923-1954, Ankara.

Historiska Institutionen (2010) http://www.historia.su.se/ urbanhistory/eauh/papers/r2_bournova. pdf.

KGMA (Red Crescent General Directorate Archive). K. No. 2603, D. No. 1941- 1943/9-4. The report prepared by Turkish Red Crescent Association Istanbul agency and sent to Red Crescent Association General HQ, dated 23rd September 1941, numbered 7364.

KGMA. K. No. 2603, D. No. 1941-1943/9-4. The report prepared by Red Crescent Association Istanbul Directorate, sent to Red Crescent General Directorate, dated 26th December 1941, numbered 10111.

KGMA. K. No. 2603, D. No. 1941-1943/9-4. The report prepared by Red Crescent representative of Greece; Saim I. Umar, sent to Red Crescent General Association Directorate dated 26th October 1941 numbered 21474.

KGMA. K. No. 2603, D. No. 1941-1943/9-4. The report prepared by Turkish Consulate of Athens-Piraeus, sent to Red Crescent General Directorate, dated October 1941, numbered 667/265.
KGMA. K. No. 2603, D. No. 1941- 1943/9-4. The report prepared by Red Crescent Association Istanbul Directorate, sent to Red Crescent General Directorate dated 26th December 1941 numbered 10111.

KGMA. K. No. 2603, D. No. 1941-1943/9-4. The report prepared by Greek Relief Delegation sent to Red Crescent General Directorate dated 22nd November 1941 numbered 41.

KGMA. K. No. 2603, D. No. 1941- 1943/9-4. The report prepared by Red Crescent Greece delegate S. İ. Umar to Red Crescent Association General Directorate dated 25th December 1941 numbered 5.

KGMA. K. No. 2603, D. No. 1941- 1943/9-4. The report prepared by Red Crescent Greece delegate Saim İ. Umar to Red Crescent Association General Directorate dated 19th January 1942 numbered 6 (969).

KGMA. K. No. 2603, D. No. 1941- 1943/9-4. The report prepared by Red Crescent Greece delegate Saim İ. Umar to Red Crescent Association General Directorate dated 27th January 1942 numbered 7 (1622).

KGMA. K. No. 2599, D. No. 1942/9-4. The report prepared by Transportation Ministry; Naval Transport Department to Red Crescent General Association dated 21st November 1942 numbered 1289.

KGMA. K. No. 2599, D. No. 1942/9-4. The report prepared by Red Crescent Association Istanbul Agency to Red Crescent General Association dated 7th February 1942 numbered 91 (2335).

KGMA. K. No. 2599, D. No. 1942/9-4. The report prepared by Red Crescent Greece Relief Delegate Saim İ. Umar to Red Crescent Association General Directorate dated 10th March 1942 numbered 8 (4988).

KGMA. K. No. 2599, D. No. 1942/9-4. The report prepared by Red Crescent General Directorate Association sent to Foreign Affairs Ministry dated 13th March 1942 numbered 4007/163. 
KGMA. K. No. 2660, D. No. 1945-1953/9-4. The report prepared by Ministry of Medicine and Health sent to Red Crescent Association General Directorate dated 3rd March 1942 numbered 4592 (4388).

KGMA. K. No. 2599, D. No. 1942/9-4. The report prepared by Red Crescent Greece Relief Delegate Saim İ. Umar to Red Crescent Association General Directorate dated 8th April 1942 numbered 9 (7272).

KGMA. K. No. 2599, D. No. 1942/9-4. The report prepared by Red Crescent Greece relief Delegate Saim İ. Umar to Red Crescent Association General Directorate dated 7th May 1942 numbered 10 (9362).

KGMA. K. No. 2599, D. No. 1942/9-4. The report prepared by Red Crescent Association to Prime Ministry dated 30th June 1942 numbered 13237.

KGMA. K. No. 2599, D. No. 1942/9-4. The report prepared by Red Crescent Association sent to Istanbul Red Crescent Agency dated 18th August 1942 numbered 15041/305.
KGMA. K. No. 2599, D. No. 1942/9-4. The report prepared by Red Crescent Association Istanbul Agency sent to Prime Ministry dated 8th June 1942 numbered 524 (11620).

KGMA. K. No. 2599, D. No. 1942/9-4. The report prepared by Red Crescent Association sent to Feridun Demokan dated 30th June 1942 numbered 13237.

KGMA. Feridun Demokan Private (Diary) Archive

Mazower, M. (1993) Inside Hitler's Greece; The Experience of Occupation 1941-1944, London, New Haven ve Londra Yale University Press.

Moos, H. V. (1952) Büyük Dünya Olayı, Cilt II, Istanbul, General Staf Publications.

Rowland, L. (2000) The Survival of Titch, Efstathiadis Group, Athens.

Soysal, İ. (1983) Tarihçeleri ve Açıklamalarıyla Birlikte Türkiye’nin Siyasal Andlaşmaları, Cilt I, Ankara. 